\title{
Trend of transplants and organ and tissue donations in Brazil: a time series analysis
}

\author{
Tendência dos transplantes e doações de órgãos e tecidos no Brasil: análise de séries temporais \\ Tendencia de trasplantes y donaciones de órganos y tejidos en Brasil: análisis de la serie de tiempos
}

Fernanda Gatez Trevisan dos Santos'
ORCID: 0000-0001-7082-6949

Vanessa Aparecida Martim Mezzavila'

ORCID: 0000-0001-8163-7908

Thamires Fernandes Cardoso da Silva Rodrigues' ORCID: 0000-0001-7942-4989

Luana Cristina Bellini Cardoso' ORCID: 0000-0001-8460-1177

Marcelo da Silva' ORCID: 0000-0002-0376-0430

Rosana Rosseto de Oliveira' ORCID: 0000-0003-3373-1654

Cremilde Aparecida Trindade Radovanovic' ORCID: 0000-0001-9825-3062

'Universidade Estadual de Maringá. Maringá, Paraná, Brazil.

How to cite this article:

Santos FGT, Mezzavila VAM, Rodrigues TFCS, Cardoso LCB, Silva M, Oliveira RR, et al. Trend of transplants and organ and tissue donations in Brazil: time series analysis. Rev Bras Enferm. 2021;74(1):e20200058. doi: http://dx.doi. org/10.1590/0034-7167-2020-0058

Corresponding author:

Thamires Fernandes Cardoso da Silva Rodrigues E-mail: tfcsrodrigues@gmail.com

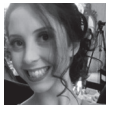

EDITOR IN CHIEF: Antonio José de Almeida Filho ASSOCIATE EDITOR: Ana Fátima Fernandes

Submission: $05-26-2020$

Approval: 08-17-2020

\begin{abstract}
Objectives: to indentify the time trend of rates of organs and tissues effective donors, of reports and types of transplanted organs per million people of the Brazilian population. Methods: ecological study, of time series, about reports of organ donations and on transplants. The data were provided by the Registro Brasileiro de Transplantes and analyzed using polynomial regression. Results: an increasing trend was found for potential donors and effective donors, with an average increase of 2.33 and 0.92 per year, respectively. The South Region had the highest rate of potential donors (83.8) and effective donors (34.1) and the North Region, the lowest rate (20.2 and 3.9). The family refusal was the main obstacle to accomplish the donation. Conclusions: the results show an increasing trend of potential donors and effective donors throughout Brazil, with emphasis on the southern region of the country. Among the main reasons for non-donation, it is worth emphasizing family refusal and medical contraindication prescription.

Descriptors: Transplant; Tissue and Organ Procurement; Databases as Topic; Epidemiology; Brazil.
\end{abstract}

\section{RESUMO}

Objetivos: identificar a tendência temporal das taxas de doadores efetivos de órgãos e tecidos, de notificações e tipos de órgãos transplantados por milhão da população no Brasil. Métodos: estudo ecológico, de séries temporais, sobre notificações de doações de órgãos e transplantes. Os dados foram fornecidos pelo Registro Brasileiro de Transplantes e analisados por meio de regressão polinomial. Resultados: detectou-se tendência crescente de potenciais doadores e doadores efetivos, com aumento médio ao ano de 2,33 e 0,92, respectivamente. A Região Sul apresentou a maior taxa de potenciais doadores $(83,8) \mathrm{e}$ doadores efetivos $(34,1)$ e a Região Norte, a menor $(20,2$ e 3,9). A recusa familiar consistiu no principal impedimento para efetivar a doação. Conclusões: os resultados demonstram tendência crescente de potenciais doadores e doadores efetivos em todo o Brasil, com destaque para a região Sul. Dentre os principais motivos para a não doação, destacam-se a recusa familiar e a contraindicação médica.

Descritores: Transplante; Obtenção de Tecidos e Órgãos; Bases de Dados como Assunto; Epidemiologia; Brasil.

\section{RESUMEN}

Objetivos: identificar la tendencia temporal de las tasas de donantes efectivos de órganos y tejidos, de notificaciones y tipos de órganos trasplantados por millón de población en Brasil. Métodos: estudio ecológico, de series temporales, sobre notificaciones de donaciones y trasplantes de órganos. Los datos fueron proporcionados por el Registro Brasileño de Trasplantes, analizados mediante regresión polinomial. Resultados: se detectó una tendencia creciente para donantes potenciales y donantes efectivos, con un incremento promedio de 2,33 y 0,92 por año. La Región Sur tuvo la tasa más alta de donantes potenciales $(83,8)$ y donantes efectivos $(34,1)$ y la Región Norte, la más baja $(20,2$ y 3,9). La negativa familiar fue el principal impedimento para efectuar la donación. Conclusiones: los resultados demuestran una tendencia creciente de donantes potenciales y donantes efectivos en todo Brasil, con énfasis en la Región Sur. Entre los principales motivos para no donar destacan el rechazo familiar y contraindicación médica.

Descriptores: Trasplante; Obtención de Tejidos y Órganos; Bases de Datos como Asunto; Epidemiología; Brasil. 


\section{INTRODUCTION}

Organ transplants have been growing systematically in Brazil, however, although the numbers are promising, the high demand for organs means that patients have to wait in a waiting list ${ }^{(1)}$. In 2017 , there were about 11,000 potential donors, 3,415 effective donors, with around 7,500 organ transplants. However, in 2018, the rate of effective donors increased by only $2.4 \%$, changing from 16.6 transplants per million people (pmp) in 2017 to $17.0 \mathrm{pmp}$ in 2018. These rates were $5.5 \%$ lower than the expected ( $18.0 \mathrm{pmp}$ ). However, the observed increase is because of the $0.6 \%$ increase in the reporting rate of potential donors and $2.2 \%$ in the donation effectiveness rate. Furthermore, the increase in deceased donors was $0.7 \%$, demonstrating that there was an increase in the percentage of non-use of deceased donor organs ${ }^{(2)}$.

In 2019, 11,399 potential donors were registered, about 54.7 pmp, growing by $6 \%$ over the year before and 3,768 effective donors ( $18.1 \mathrm{pmp})$, increasing by $7 \%{ }^{(3)}$. In 2020 , the year in which the COVID-19 pandemic changed the world scenario, causing thousands of deaths, with severe consequences in different areas of society; thus, the Brazilian donation and transplantation program will also be affected. However, this negative scenario should only be noticed in the second and third quarters, considering that country's situation worsened only in March. For this reason, from January 2020 to March 2020, the number of potential donors reported was 2,730 (52.0 pmp), similar to the same period in 2019 (52.2 pmp), in which the number of effective donors was 965 (18.4 pmp), being higher than last year ${ }^{(4)}$.

In Brazil, in 2019, 37,946 people were waiting for an organ, showing that there is an imbalance in the range of donors and recipient individuals, making it one of the reasons for the little progress expected of current donors. To decrease the waiting period for a transplant, it is necessary to invest in the entire process $^{(5)}$. It is worth mentioning that the observed increase in the rate of effective donors can be partly associated to the efforts to report potential donors, however, the effective rates remained unchanged. Thus, it appears that the rates of family authorization have not changed, nor have the contraindications been reduced ${ }^{(3)}$.

Thus, it is known that, for many people, transplantation is the only therapeutic alternative that will provide quality of life for them. The donation of multi-organs, tissues and cells from a single deceased donor can benefit about ten recipient individuals ${ }^{(6)}$. However, although in recent years, donation rates have increased in several countries, there is a disproportion between supply and demand for organs, with the number of effective donations being less than the number of people waiting for a transplant ${ }^{(7-8)}$.

This way, the process of donating organs, tissues and cells proves to be complex, requiring the ability of the services to transform potential donors into effective donors ${ }^{(9)}$. The potential donor is the person with a confirmed brain death (BD) diagnosis and who has no clinical contraindication prescription to have the transplant done, becoming an effective donor only when there is a surgical incision, upon the family authorization ${ }^{(10)}$.

Therefore, the waiting list for a transplant has expanded, and a smaller number of potential donors and effective donors has been reported to the transplant centers, because, although there is a massive campaign for organ donation by the health services communication, there are other determinants that make transplants more difficult. As a result, few Brazilian publications address the theme broadly, working in a fragmented manner and with secluded regions of the country. Therefore, this study seeks to produce subsidies that promote changes in government actions that aim to improve organ procurement and transplantation, since there are compilation and analysis of information from all Brazilian states. In this perspective, this research has the following question: what is the time trend of the rates of the potential donors, effective donors, corneal transplant, kidney transplant, pancreas transplant, heart transplant and lung transplants, as well as the main reasons for non-donation in Brazil in the last ten years?

\section{OBJECTIVES}

To indentify the time trend of rates of organ and tissue effective donors, reports, and types of organs transplanted pmp in Brazil.

\section{METHODS}

\section{Ethical aspects}

The study respected the guidelines controlled by the National Health Council of the Ministry of Health, through Resolution no. $466 / 12$. As it is public access data, it was released from the evaluation of the Standing Committee on Ethics in Research with Human Beings of the participant institution.

\section{Design, period, and setting}

Ecological study, of time series, about the reports of organ donations and transplants carried out in Brazil, from 2008 to 2017, available in the Registro Brasileiro de Transplantes (RBT), of residents in Brazil ${ }^{(11)}$. The Strengthening the Reporting of Observational Studies in Epidemiology (STROBE) was used to guide the study methodology.

This study period was chosen because it has the most complete and current records available at RBT. We chose to use the Brazilian Statistics Institute (IBGE) division, which separates the country into five macro-regions, which were the units of analysis: North, Northeast, Midwest, Southeast and South ${ }^{(12)}$.

The RBT is a platform of the Brazilian Association of Organs Transplantation (ABTO) that provides data about organ and tissue donation and transplantation in the country to the scientific community and the population. It makes public domain data available, which can be found in four annual reports, three of them being partial and a complete one at the end of each year. For this study, only the final reports were used. The information in the reports refers to the global transplant dimension, Brazilian death data per year in hospitals, potential donors, effective donors, kidney, liver, heart, pancreas, lung, bone marrow, bone and corneal transplants, waiting list, pediatric transplants and reasons for not donating organs and tissues ${ }^{(11)}$.

\section{Data collection procedures}

Data collection on RBT platform was proceeded in October 2018. Based on the available information, the researchers created 
Trend of transplants and organ and tissue donations in Brazil: a time series analysis Santos FGT, Mezzavila VAM, Rodrigues TFCS, Cardoso LCB, Silva M, Oliveira RR, et al.

an instrument in the Microsoft Office Excel 2013 program to systematize data collection on electronic spreadsheets. These were doubly inputted in a spreadsheet, and the inconsistencies were corrected. Initially, the gross data organization was done, then the arrangement of the years in columns and the states in rows. After, the data were compiled by macro-regions. This process was repeated for the following variables: potential donors and effective donors, kidney, liver, heart, pancreas, lung, and corneal transplants. To calculate the rate of kidney transplantation, the rates of living and deceased donors were added, and to identify the reasons for not donating organs and tissues in Brazil, it was used information related to family refusal, cardiac arrest and medical contraindication prescription.

\section{Analysis of results and statistics}

The reporting rates of potential donors and real donors per year were calculated pmp. The polynomial linear regression model was used to analyze the trend in the notification rates of potential and effective donors. Effective donor rates were considered a dependent variable $(\mathrm{Y})$ and years of study as an independent variable (X). Initially, dispersion diagrams were carried out, with attenuated series by calculating the three-point moving average. Simple linear regression models were tested $\left(y=\beta_{0}+\beta_{1 x}\right)$ and, if the series behavior indicated a need, second-order models $\left(y=\beta_{0}+\beta_{1 x}+\beta_{2 x}{ }^{2}\right)$. It was not necessary to use third order models $\left(y=\beta 0+/-\beta 1 X+/-\beta 2 X^{2}+/\right.$ $\beta 3 \times 3)$. It was determined that the most appropriate polynomial model was the one that obtained best statistical relevance with better determination and residual coefficient without bias. All analyzes were conducted using the statistical software SPSS (Statistical Package for the Social Sciences), version 20.1 $1^{(14-15)}$.

\section{RESULTS}

In Brazil, from 2008 to 2017, a total of 83,431 potential donors and 23,816 effective donations were reported. There was an increase in reports of potential donors and effective donations across the country. In the year 2017, the South and North Regions stood out from the others, being the South Region with the highest rate of potential donors (83.8 pmp) and effective donors (34.1 pmp) and the North Region with the lowest rate of potential donors (20.2 pmp) and effective donors (3.9 pmp) in the country.

The rates of potential donors and effective donors remained increasing throughout the time interval analyzed (annual mean increase of 2.33 and 0.97, respectively). The South Region presented an annual mean increase in the rates of potential donors $\left(5,58 \mathrm{pmp}, \mathrm{r}^{2}=0,99\right)$ and effective donors $\left(2,39 \mathrm{pmp}, \mathrm{r}^{2}=0,98\right)$, higher than the national average (Table 1 ).
Table 1 - Models of the trend in the rates of potential donors and effective donors per million population, according to region, Brazil, from 2008 to 2017

\begin{tabular}{|c|c|c|c|c|c|}
\hline & $\beta_{0}$ & $\beta_{1}^{+}$ & Coefficient & $p^{*}$ & Trend \\
\hline \multicolumn{6}{|l|}{ Potential donors } \\
\hline Brazil & 41.91 & $2.33^{+}$ & 0.97 & $<0.001$ & $\uparrow$ \\
\hline Midwest & 46.77 & $2.66^{\dagger}$ & 0.87 & 0.001 & $\uparrow$ \\
\hline Northeast & 33.82 & $2.38^{\dagger}$ & 0.85 & 0.001 & $\uparrow$ \\
\hline North & 16.42 & $2.56^{\dagger}$ & 0.86 & 0.001 & $\uparrow$ \\
\hline Southeast & 48.35 & $1.19^{\dagger}$ & 0.95 & $<0.001$ & $\uparrow$ \\
\hline South & 51.48 & $5.58^{+}$ & 0.99 & $<0.001$ & $\uparrow$ \\
\hline \multicolumn{6}{|l|}{ Effective donors } \\
\hline Brazil & 11.85 & $0.92^{\dagger}$ & 0.98 & $<0.001$ & $\uparrow$ \\
\hline Midwest & 6.93 & $0.78^{\dagger}$ & 0.98 & $<0.001$ & $\uparrow$ \\
\hline Northeast & 7.94 & $0.77^{\dagger}$ & 0.92 & $<0.001$ & $\uparrow$ \\
\hline North & 2.45 & $0.39^{\dagger}$ & 0.82 & 0.002 & $\uparrow$ \\
\hline Southeast & 14.97 & $0.63^{\dagger}$ & 0.83 & 0.001 & $\uparrow$ \\
\hline South & 18.27 & $2.39^{\dagger}$ & 0.98 & $<0.001$ & $\uparrow$ \\
\hline
\end{tabular}

Table 2 - Models of the trend in the rates of transplanted organs and tissues per million people, according to region, Brazil, from 2008 to 2017

\begin{tabular}{|c|c|c|c|c|c|c|c|}
\hline & 2008-2012 & 2013-2017 & $\beta_{0}$ & $\beta_{1}$ & Coefficient & $\boldsymbol{p}^{*}$ & Trend \\
\hline \multicolumn{8}{|l|}{ Cornea } \\
\hline Brazil & 73.2 & 70.8 & 72.04 & $0.20^{\|}$ & 0.03 & 0.659 & - \\
\hline Midwest & 96.5 & 102.6 & 98.83 & $2.46^{+}$ & 0.30 & 0.160 & - \\
\hline Northeast & 44.3 & 54.9 & 48.53 & $2.21^{+}$ & 0.72 & 0.008 & $\uparrow$ \\
\hline North & 19.6 & 31.0 & 24.20 & $2.33^{\dagger}$ & 0.92 & $<0.001$ & $\uparrow$ \\
\hline Southeast & 96.3 & 81.2 & 89.37 & $2.18^{+}$ & 0.95 & $<0.001$ & $\downarrow$ \\
\hline South & 79.9 & 78.0 & 80.46 & $0.12^{+}$ & 0.01 & 0.860 & - \\
\hline \multicolumn{8}{|l|}{ Kidney** } \\
\hline Brazil & 12.32 & 14.18 & 13.89 & $0.48^{+}$ & 0.98 & $<0.001$ & $\uparrow / \downarrow$ \\
\hline Midwest & 6.34 & 6.65 & 6.58 & $0.02^{\dagger}$ & 0.01 & 0.848 & - \\
\hline Northeast & 6.47 & 7.93 & 7.17 & $0.29^{\dagger}$ & 0.75 & 0.005 & $\uparrow$ \\
\hline North & 2.49 & 3.16 & 3.32 & $0.26^{+}$ & 0.92 & 0.001 & $\uparrow / \downarrow$ \\
\hline Southeast & 16.96 & 18.77 & 18.64 & $0.46^{+}$ & 0.97 & $<0.001$ & $\uparrow / \downarrow$ \\
\hline South & 18.6 & 23.1 & 20.59 & $0.90^{\dagger}$ & 0.79 & 0.003 & $\uparrow$ \\
\hline \multicolumn{8}{|l|}{ Liver } \\
\hline Brazil & 7.5 & 9.3 & 8.24 & $0.34^{\dagger}$ & 0.95 & $<0.001$ & $\uparrow$ \\
\hline Midwest & 0.6 & 4.4 & 2.06 & $0.78^{+}$ & 0.96 & $<0.001$ & $\uparrow$ \\
\hline Northeast & 5.0 & 6.7 & 6.46 & $0.44^{\dagger}$ & 0.95 & $<0.001$ & $\uparrow / \downarrow$ \\
\hline North & - & 0.4 & 0.15 & $0.09^{\dagger}$ & 0.88 & $<0.001$ & $\uparrow$ \\
\hline Southeast & 10.8 & 11.7 & 11.24 & $0.14^{\dagger}$ & 0.84 & 0.001 & $\uparrow$ \\
\hline South & 10.3 & 15.2 & 11.99 & $0.95^{\dagger}$ & 0.97 & $<0.001$ & $\uparrow$ \\
\hline \multicolumn{8}{|l|}{ Pancreas } \\
\hline Brazil & 0.8 & 0.6 & 0.76 & $0.03^{\ddagger}$ & 0.93 & $<0.001$ & $\downarrow$ \\
\hline Midwest & 0.1 & 0.1 & 0.10 & $0.01^{\dagger}$ & 0.04 & 0.617 & - \\
\hline Northeast & 0.1 & 0.2 & 0.22 & $0.02^{+}$ & 0.93 & 0.001 & $\uparrow / \downarrow$ \\
\hline North & - & - & - & - & - & - & - \\
\hline Southeast & 1.6 & 1.0 & 1.34 & $0.13^{\dagger}$ & 0.97 & $<0.001$ & $\downarrow$ \\
\hline South & 1.0 & 1.3 & 1.06 & $0.08^{+}$ & 0.85 & 0.001 & $\uparrow$ \\
\hline \multicolumn{8}{|l|}{ Heart } \\
\hline Brazil & 1.0 & 1.6 & 1.24 & $0.1^{\dagger}$ & 0.90 & $<0.001$ & $\uparrow$ \\
\hline Midwest & 0.6 & 2.3 & 1.29 & $0.33^{+}$ & 0.97 & $<0.001$ & $\uparrow$ \\
\hline Northeast & 0.7 & 1.2 & 0.88 & $0.10^{+}$ & 0.92 & $<0.001$ & $\uparrow$ \\
\hline North & - & - & - & - & - & - & - \\
\hline Southeast & 1.4 & 2.2 & 1.70 & $0.15^{\dagger}$ & 0.85 & 0.001 & $\uparrow$ \\
\hline South & 1.3 & 1.9 & 1.40 & $0.15^{\dagger}$ & 0.84 & 0.001 & $\uparrow$ \\
\hline \multicolumn{8}{|l|}{ Lung } \\
\hline Brazil & 0.3 & 0.4 & 0.36 & $0.02^{\dagger}$ & 0.93 & $<0.001$ & $\uparrow$ \\
\hline Midwest & - & - & - & - & - & - & - \\
\hline Northeast & - & 0.1 & 0.13 & $0.03^{+}$ & 0.89 & 0.002 & $\uparrow / \downarrow$ \\
\hline North & - & - & - & - & - & - & - \\
\hline Southeast & 0.3 & 0.5 & 0.37 & $0.04^{\dagger}$ & 0.94 & $<0.001$ & $\uparrow$ \\
\hline South & 1.1 & 1.2 & 1.12 & $0.01^{\dagger}$ & 0.58 & 0.050 & $\uparrow$ \\
\hline
\end{tabular}

Note: * Significance level; **Sum of living and deceased donors; + Annual mean increase; $\neq$ Annual mean decrease; - stability; $\uparrow$ growing trend; $\downarrow$ decreasing trend; $\uparrow / \downarrow$ increasing/decreasing trend. 
Regarding the transplanted organs and tissues, there was an increasing trend towards corneal transplantation in the North and Northeast regions, with a mean increase of $2.33\left(r^{2}=0.92\right)$ and 2.21 $\left(r^{2}=0.72\right)$, respectively, and decreasing in the Southeast Region, with a mean decrease of 2.18 per year $\left(r^{2}=0.95\right)$. Kidney transplantation showed an increasing trend in the Northeast and South Regions, with an annual mean increase of $0.29\left(r^{2}=0.75\right)$ and $0.90\left(r^{2}=\right.$ 0.79), respectively. Liver transplantation, on the other hand, has increased throughout Brazil, except for the Northeast Region, which, until the year 2013, has grown with a subsequent decline (annual mean increase of $0.44 ; r^{2}=0.95$ ) (Table 2). In Brazil, pancreas transplantation showed a decreasing trend (annual mean decrease of $\left.0.03 ; r^{2}=0.90\right)$. However, the South Region showed an annual mean increase of $0.08\left(r^{2}=0.85\right)$. Regarding heart donations, it was observed an increasing trend across the country (annual mean increase of $\left.0.13 ; r^{2}=0.90\right)$. Lung transplants, on the other hand, showed an increasing trend in the Southeast and South Regions (annual mean increase of 0.04 and 0.01, respectively) (Table 2).

As for the reasons for not donating organs, it was observed that the family refusal was the main obstacle to achieve the donation in the five-years analyzed, with $34.54 \%$ of family refusal from 2008 to 2012 and $36.59 \%$ of family refusal from 2013 to 2017 . There was a decrease in non-donations due to cardiac arrest, from $25.40 \%$ to 18.00\% from 2008 to 2012 and from 2013 to 2017. In the Midwest Region, the major reason was the medical contraindication prescription in both analyzed periods (39.86\% and 35.51\%) (Table 3).

Table 3 - Reasons for not donating organs, according to regions of Brazil, from 2008 to 2017

\begin{tabular}{|c|c|c|c|c|}
\hline $\begin{array}{l}\text { Region and } \\
\text { period }\end{array}$ & $\begin{array}{l}\text { Family } \\
\text { refusal } \\
n(\%)\end{array}$ & $\begin{array}{c}\text { Cardiac } \\
\text { arrest } \\
\text { n (\%) }\end{array}$ & $\begin{array}{c}\text { Medical } \\
\text { contraindication } \\
\text { prescription } \\
\mathbf{n}(\%)\end{array}$ & $\begin{array}{l}\text { Others } \\
\text { n (\%) }\end{array}$ \\
\hline Brazil & & & & \\
\hline $\begin{array}{l}2008-2012 \\
2013-2017\end{array}$ & $\begin{array}{c}8771(34.54) \\
12156(36.59)\end{array}$ & $\begin{array}{l}6450(25.40) \\
5980(18.00)\end{array}$ & $\begin{array}{l}4599(18.11) \\
7068(21.28)\end{array}$ & $\begin{array}{l}5577(21.96) \\
8014(24.13)\end{array}$ \\
\hline $\begin{array}{l}\text { Midwest } \\
2008-2012 \\
2013-2017\end{array}$ & $\begin{array}{c}533(21.84) \\
1107(32.81)\end{array}$ & $\begin{array}{l}561(22.98) \\
297(8.80)\end{array}$ & $\begin{array}{c}973(39.86) \\
1198(35.51)\end{array}$ & $\begin{array}{l}374(15.32) \\
772(22.88)\end{array}$ \\
\hline $\begin{array}{l}\text { Northeast } \\
2008-2012 \\
2013-2017\end{array}$ & $\begin{array}{l}2115(36.62) \\
3083(38.24)\end{array}$ & $\begin{array}{l}888(1537) \\
856(10.62)\end{array}$ & $\begin{array}{l}1120(19.39) \\
21.60(26.79)\end{array}$ & $\begin{array}{l}1653(28.62) \\
1963(24.35)\end{array}$ \\
\hline $\begin{array}{l}\text { North } \\
2008-2012 \\
2013-2017\end{array}$ & $\begin{array}{l}314(42.32) \\
563(33.77)\end{array}$ & $\begin{array}{l}114(15.36) \\
113(6.78)\end{array}$ & $\begin{array}{l}175(23.58) \\
307(18.42)\end{array}$ & $\begin{array}{l}139(18.73) \\
684(41.03)\end{array}$ \\
\hline $\begin{array}{l}\text { Southeast } \\
2008-2012 \\
2013-2017\end{array}$ & $\begin{array}{l}3644(29.68) \\
5431(36.70)\end{array}$ & $\begin{array}{l}4024(32.77) \\
3488(23.57)\end{array}$ & $\begin{array}{l}1422(11.58) \\
1787(12.08)\end{array}$ & $\begin{array}{l}3188(25.97) \\
4093(27.66)\end{array}$ \\
\hline $\begin{array}{l}\text { South } \\
\qquad 2008-2012 \\
2013-2017\end{array}$ & $\begin{array}{l}1633(44.91) \\
2606(43.08)\end{array}$ & $\begin{array}{c}872(23.98) \\
1217(20.12)\end{array}$ & $\begin{array}{c}908(24.97) \\
1707(28.22)\end{array}$ & $\begin{array}{l}223(6.13) \\
519(8.58)\end{array}$ \\
\hline
\end{tabular}

\section{DISCUSSION}

The increase in potential donors and actual donor reports is in line with that observed in other countries ${ }^{(11,16)}$. Europe highlights on the world scenario, since in the year 2015, a total of 32,707 organs were transplanted. Spain and Croatia had a rate of 40.2 pmp donors, followed by Belgium, with $31.6 \mathrm{pmp}$ donors, and Portugal, with 31.0 pmp donors ${ }^{(16)}$. In the same year, the United
States showed a rate of 28.2 pmp donors and Canada showed a rate of 19.0 pmp donors ${ }^{(16)}$. Brazil is in the second position concerning the number of South Americans effective donors, only behind Uruguay, which has a rate of 16.8 pmp donors ${ }^{(11)}$.

Although the country has a worldwide organ, tissue and cell transplantation program, due to its large territorial extension, there are disparities that affect donation rates, such as socioeconomic conditions. The South and Southeast Regions concentrate the largest geo-economics areas, infrastructure and transport, offering more health services and access to education than other locations ${ }^{(17)}$. Therefore, the health services in these regions possibly have features that support organ procurement, distribution, and transplantation due to the available resources and technological density, as well as the training and qualification of the teams that work in this field.

It is noteworthy that the Distrito Federal (DF), Paraná, Mato Grosso do Sul and Santa Catarina presented more than 80 potential donors pmp, and only Santa Catarina and Paraná achieved donation accomplishment rates above $40 \%$ and 40 pmp of effective donors, with values similar to those found in developed countries $^{(3,11,16)}$. Concerning the state of Santa Catarina, the results can be associated with the effort of the Transplantation Center, which systematized tools for organizing the process, as a way to standardize care, assign greater safety and guide care to patients with $\mathrm{BD}$, simplifying and optimizing the donation and transplantation process ${ }^{(11,18)}$.

In this perspective, the state governments of Santa Catarina and Paraná invested in the continuing education of professionals. The qualification of those involved is crucial for reducing the weaknesses of the process, by bringing on analytical, reflective and critical thinking health professionals, making them skilled and sensitive to deal with potential donors and their families ${ }^{(10,19)}$.

Moreover, the state government of Paraná joined the National Plan for Organ Procurement Organizations (OPOs) as a measure to encourage the promotion of actions related to transplantation. This contributed to speed up the process from reporting to effective transplantation, besides establishing the Programa de Apoio e Qualificação de Hospitais Públicos e Filantrópicos do SUS Paraná (HOSPSUS), that aims to reinforce and improve hospital care until the year 2020, financing and encouraging health establishments to join the program, including the organ and tissue procurement and donation targets ${ }^{(20)}$.

The results of this study also show disparities between the rates of potential donors and actual donors in all regions. From the year 2010 to 2017, effective donor rates increased by $69 \%$, from 9.9 donors pmp to 16.7 donors pmp, and the potential donor notification rate increased by $41 \%^{(11)}$.

Despite this significant scenario, there are obstacles that hinder the advancement of transplants in Brazil( ${ }^{(9)}$. The logistics and infrastructure aspects of hospitals and the National Transplant System (SNT) deserve attention. Because, in some locations, access to air transport to perform the organs and tissues transfer is limited, besides the unavailability of procurement and implant teams.

Regarding the disproportion between the demand and the supply of organs detected in this study, similar results were observed in the literature. In the year 2017, Brazil had an estimated demand for 39,362 organs and tissues (cornea, kidney, heart, 
liver, and lung), however only 23,742 were transplanted without considering the demand for other organs ${ }^{(11)}$. Although the organ donation rate shown by Spain is significant, the country had a waiting list for the transplant of approximately 5,500 people. Similarly, the UK had around 7,000 people waiting for a transplant ${ }^{(21)}$. Simultaneously to the unavailability of organs, many patients who have already been transplanted return to the waiting list. In the United States, $30 \%$ of people on the waiting list count on their second transplant and 18 people die every day ${ }^{(22-23)}$.

When it comes to the differences in the trend of transplanted organs among the regions detected in this study, the RBT found that, in the last ten years, liver, heart, kidney and lung transplants were increased by $85 \%, 100 \%, 71 \%$ and $67 \%$, respectively. According to the report, the states of Mato Grosso and Sergipe have not had kidney transplants in years, and Amapá, Roraima and Tocantins have never performed this procedure ${ }^{(11)}$.

Research carried out from 2012 to 2014 found that Northeast and Southeast had the largest number of patients waiting for corneal transplantation, with the Southeast meeting near $70 \%$ of this demand ${ }^{(24)}$. The results obtained show that the North and Northeast Regions face difficulties in the corneal procurement and donation processes, which are related to the disruption of programs, low report rate, employee strikes, shortage of trained professionals and poor hospital infrastructure ${ }^{(24)}$.

Regarding the reasons for not donating organs, it was observed that family refusal and medical contraindication prescriptions were the main causes. These findings are in line with what is found in the national and international literature ${ }^{(9-10,23)}$. Family consent to organ donation includes several processes. Family members need to deal with a stressful situation in which sadness is mixed with decision making, and it is necessary to deal with their beliefs and attitudes about organ donation and the desires evoke of the deceased. Nevertheless, this situation is settled by the interaction among different health professionals, whose behavior, care, way of presentation and requesting the donation can influence the feelings of family members during grief and, consequently, in their choice ${ }^{(25)}$.

Among the reasons for family refusal it is highlighted the religious beliefs, fear of violation/handling of the body, misunderstanding about the diagnosis of $\mathrm{BD}$, misinformation of the desire of the potential donor and/or the manifestation against donation while living, dissatisfaction with the received service, time-related to logistics that involves the donation and the inappropriate place to conduct the family interview ${ }^{(6-7)}$. Understanding the reasons for refusal, subsidies can be produced that contribute to the development of strategies that benefit the donation of organs and tissues ${ }^{(6)}$.

In this perspective, it is emphasized that health workers should discuss the issue, as they are essential to the process and they are close to the family. Thus, although organ donation, procurement and transplantation are standardized and regulated, the teams have difficulty dealing with the desires of family members ${ }^{(7)}$. Assistance to families with loved ones who have been diagnosed with BD should be based on respect, humanization and acceptance, with awareness to the needs of family members and listening for them to express their experiences and feelings, so that the well-being of those involved be equal or more important than the consent to the donation ${ }^{(26-27)}$.
Another important aspect pointed out by the literature when dealing with families is the professional experience, since up to $80 \%$ of people consent to the donation when they are approached by experienced and trained professionals. In contrast, there is only $35.5 \%$ of agreement when they are inexperienced ${ }^{(21,24)}$. The role of the nurse is highlighted, as his assistance is based on the particularities of each family, creating bonds of respect and trust, through the dialogical relationship, acting as caregiver, educator and facilitator for donation ${ }^{(28)}$.

\section{Study limitations}

The research has limitations, as it uses secondary data from RBT, which is subject to underreporting and absence of information. As a result, the RBT underwent improvements in the year 2012, which added new topics to the questionnaire sent to the State Transplant Centers, so that some retroactive data are unavailable in the system. However, despite these aspects, the system has been increasingly regulated and consolidated, besides allowing a progressive improvement in organ donation and transplantation ${ }^{(11)}$.

\section{Contributions to the field of nursing, health, or public policies}

It is believed this research data provide subsidies for monitoring and evaluation of the condition of donations and organ and tissue transplants in Brazil, in addition to recognize the main obstacles to their effectiveness. Therefore, subsidies were produced that can help the public administration to guide health policies, by concentrating efforts in regions where there is a low report or minor relationship between a potential donor and an effective donor, also in places where the family refusal is high. The importance of stimulating the training of professionals involved in the organ procurement and transplantation process is highlighted, especially those who carry out the family interview, to make them more sensitive to the feelings, experiences and desires of the families who are experiencing the struggle and need to make an important decision. This will certainly be essential for the consent of the donation.

\section{CONCLUSIONS}

From the year 2008 and 2017, reports from potential donors and effective donors showed an increasing trend throughout Brazil, especially in the South Region. There was also a growing trend towards liver and heart transplantation and disparities in the trend for cornea, kidney, pancreas, and lung transplantation, among regions of the country. The main reason found for not donating organs and tissues was a family refusal. Studies are suggested to support strategies to encourage improvements in the process, to enhance organ procurement and minimize losses, to reduce the waiting line and, consequently, improve the prognosis and quality of life of recipients and their family members.

\section{FUNDING}

Study developed with the support of the Coordination for the Improvement of Higher Education Personnel - Brazil (CAPES, master's, and doctorate scholarship) - Financing Code 001. 


\section{REFERENCES}

1. Pereira KGB, Souza VS, Spigolon DN, Teston EF, Oliveira JLC, Moreira FG. Organ donation in hospital servises: the principal reasons for authorization refusals. Rev Enferm UFSM. 2020;10(4):1-14. doi: 10.5902/2179769236087

2. Associação Brasileira de Transplantes de Órgãos. Registro Brasileiro de Transplantes. Dimensionamento dos Transplantes no Brasil e em cada estado (2011-2018) [Internet]. 2018[cited 2019 Dec 12]. Available from: http://www.abto.org.br/abtov03/Upload/file/RBT/2018/Lv_RBT2018.pdf

3. Associação Brasileira de Transplantes de Órgãos. Registro Brasileiro de Transplantes. Dimensionamento dos Transplantes no Brasil e em cada estado (2012-2019)[Internet]. [cited 2020 Jan 24]. Available from: http://www.abto.org.br/abtov03/Upload/file/RBT/2019/RBT-2019leitura.pdf

4. Associação Brasileira de Transplantes de Órgãos. Registro Brasileiro de Transplantes. Dados numéricos da doação de órgãos e transplantes realizados por estado e instituição no período: janeiro/março - 2020[Internet]. 2020[cited 2020 Jul 10]. Available from: http://www.abto.org. br/abtov03/Upload/file/RBT/2020/RBT-2020-1 trim-leitura.pdf

5. Bertasi RAO, Bertasi TGO, Reigada CPH, Ricetto E, Bonfim KO, Santos LA, et al. Perfil dos potenciais doadores de órgãos e fatores relacionados à doação e a não doação de órgãos de uma Organização de Procura de Órgãos. Rev Col Bras Cir. 2019;46(3):e20192180. doi: 10.1590/0100-6991e-201922180

6. Marinho CLA, Conceição AICC, Silva RS. Causes of family refusal on the organs and tissues donation. Rev Enferm Contemp. 2018;7(1):34-39. doi: 10.17267/2317-3378rec.v7i1.2008

7. Fernandes MEN, Bittencourt ZZLC, Boin IFSF. Experiencing organ donation: feelings of relatives after consente. Rev Latino-Am Enfermagem. 2015;23(5):895-901. doi: 10.1590/0104-1169.0486.2629

8. Westphal GA, Garcia VD, Souza RL. Guidelines for the assessment and acceptance of potential brain-dead organ donors. Rev Bras Ter Intensiva. 2016;28(3):220-55. doi: 10.5935L/0103-507X.20160049

9. Barreto BS, Santana RJB, Nogueira EC, Fernandez BO, Brito FPG. Factors associated with refusal to donate organs in the state of Sergipe, Brazil. Rev Bras Pesqui Saúde. 2016;18(3):40-8. doi: 10.21722/rbps.v18i3.15741

10. Gois RSS, Galdino MJQ, Pissinati PSC, Pimentel RRS, Carvalho MDB, Haddad MCFL. Effectiveness of the organ donation process. Acta Paul Enferm. 2017;30(6):621-7. doi: 10.1590/1982-0194201700089

11. Associação Brasileira de Transplante de Órgãos. Registro Brasileiro de Transplantes [Internet]. São Paulo: ABTO, 2020. [cited 2020 Jul 10]. Available from: http://www.abto.org.br/abtov03/default.aspx?mn=457\&c=900\&s=0

12. Malta M, Cardoso LO, Bastos FI, Magnanini MMF, Silva CMFP. STROBE initiative: guidelines on reporting observational studies. Rev Saúde Pública [Internet]. 2010[cited 2020 Jul 10];44(3). Available from: http://www.consort-statement.org/consort-statement/

13. Instituto Brasileiro de Geografia e Estatística. Estimativas da população[Internet]. 2017[cited 2019 Dec 13]. Available from: https://www. ibge.gov.br/estatisticas/sociais/populacao.html

14. Rodrigues TFCS, Oliveira RR, Decesaro MN, Mathias TAF. Increase in hospital admissions for drug use in Brazil particularly in women and elderly. J Bras Psiquiatr. 2019;68(2):73-82. doi: 10.1590/0047-2085000000230

15. Latorre MRDO. Cardoso MRA. Time series analysis in epidemiology: an introduction to methodological aspects. Rev Bras Epidemiol. 2001;4(3):145-52. doi: 10.1590/S1415-790X2001000300002

16. Hart A, Smith JM, Skeans MA, Gustafson SK, Wilk AR, Robinson A, et al. OPTN/SRTR 2016 Annual Data Report: Kidney. Am J Transplant. 2018;18(Suppl 1):18-113. doi: 10.1111/ajt.14557

17. Monteiro Neto A. Desigualdades regionais no Brasil: características e tendências recentes. Bol Reg Urb Amb [Internet]. 2014 [cited 2018 Dec 13];09:67-81. Available from: http://repositorio.ipea.gov.br/bitstream/11058/5582/1/BRU_n09_desigualdades.pdf

18. Magalhães ALP, Lanzoni GMM, Knihs NS, Silva EL, Erdmann AL. Patient safety in the process of organ and tissue donation and transplant. Cogitare Enferm. 2017;(22)2:e45621. doi: 10.5380/ce.v22i1.45621

19. Aguiar F, Moreira J. Continuing Education in Health: the Problem of Organ Donation. Rev Ens Educ Cienc Human[Internet]. 2016 [cited 2019 Nov 29];17(2):153-63. Available from: http://revista.pgsskroton.com.br/index.php/ensino/article/viewFile/3946/3250

20. Quick BL, King AJ, Reynolds-Tylus T, Moore M. An evaluation of a motor vehicle facility campaign with an established statewide donor registry: a test of sustainable, evidence-based intervention strategies. Clin Transplant. 2019;33(3):e13475. doi: 10.1111/ctr.13475

21. Levitt M. Could the organ shortage ever be met? Life Sci Soc Policy. 2015;11:6. doi: 10.1186/s40504-015-0023-1

22. Stephan A. Organ Shortage: Can We Decrease the Demand? Experim Clin Transplant. 2017;(Suppl 1):6-9. doi: 10.6002/ect.mesot2016.L27

23. Tuttle-Newhall JE, Mark Schnitzler M. Getting comfortable with death: current status of organ donation. Mo Med [Internet]. 2015 [cited 2018 Dec 13];112(3):151-7. Available from: https://www.ncbi.nlm.nih.gov/pmc/articles/PMC6170131/

24. Almeida HG, Hida RY, Kara Jr N. Review of developments in corneal transplantation in the regions of Brazil: evaluation of corneal transplants in Brazil. Clinics. 2016;71(9):537-43. doi: 10.6061/clinics/2016(09)09 
25. López JS, Soria-Oliver M, Aramayona B, García-Sánchez R, Martínez JM, Martín MJ. An Integrated Psychosocial Model of Relatives'Decision About Deceased Organ Donation (IMROD): joining pieces of the puzzle. Front Psychol. 2018;9. doi: 10.3389/fpsyg.2018.00408

26. Chandler JA, Connors M, Holland G, Shemie SD. "Effective" Requesting: a scoping review of the literature on asking families to consent to organ and tissue donation. Transplantation. 2017;101(Suppl 1). doi: 10.1097/TP.0000000000001695

27. Bonetti CE, Boes AA, Lazzari DD, Busana JA, Maestri E, Bresolin P. Organ and tissue donation and reasons for its non-realization. Rev Enferm UFPE. 2017;11(9):3533-41. doi: 10.5205/reuol.10620-94529-1-SM.1109sup201705

28. Pessoa VLMP, Silva JNG, Cestari VRF, Florêncio RS, Freitas TC, Justino PRS. Outpatient nursing care: perception of the heart transplant patients on outpatient nursing consultation. Rev Pesqui Cuid Fundam. 2017;9(4):984-9. doi: 10.9789/2175-5361.2017.v9i4.984-989 